\title{
PENGARUH BANYAKNYA PERUSAHAAN INDUSTRI, JUMLAH TENAGA KERJA, JUMLAH PRODUKSI GALIAN/PERTAMBANGAN SERTA LUAS AREA PERKEBUNAN DAN PERIKANAN TERHADAP PDRB PROVINSI SULAWESI SELATAN
}

\author{
Marwan Sam ${ }^{1}$ \\ Iis Pamungkas ${ }^{2}$ \\ Muhammad Muzaini ${ }^{3 *}$ \\ ${ }^{1,2,3}$ Program Studi Matematika Universitas Cokroaminoto Palopo, Palopo, Indonesia \\ marwanprivacy@gmail.com ${ }^{1}$ \\ iispamungkas74@gmail.com ${ }^{2}$ \\ muhammadmuzaini@uncp.ac.id ${ }^{3 *}$
}

\begin{abstract}
Abstrak
Penelitian ini bertujuan untuk menganalisis pertumbuhan ekonomi di Provinsi Sulawesi Selatan menggunakan regresi linear berganda. Data yang digunakan penelitian ini yaitu data sekunder Badan Pusat Statistika (BPS) Provinsi Sulawesi Selatan selama tahun 2018. Dari penelitian diperoleh model regresi linear berganda untuk pertumbuhan ekonomi di Provinsi Sulawesi Selatan yaitu $Y=135.789+$ $5.502 X_{1}+0.180 X_{3}+1.411 X_{4}+\varepsilon$. Dari hasil analisis diperoleh adanya pengaruh positif variabel jumlah perusahan industry (X1), Jumlah Pertambangan (X3), dan luas dari area perkebunan (X4) terhadap nilai PDRB di Provinsi Sulawesi Selatan. Jika penambahan satu unit perusahaan industri di Provinsi Sulawesi Selatan maka akan meningkatkan nilai PDRB sebesar 5,502 milyar rupiah. Jika penambahan jumlah produksi pertambangan sebesar 1 juta $m 3$ di Provinsi Sulawesi Selatan maka akan meningkatkan nilai PDRB di sebesar 0,180 milyar rupiah. Sedangkan jika penambahan 1 hektar luas area perkebunan di Provinsi Sulawesi Selatan maka akan meningkatkan nilai PDRB sebesar 1,411 milyar rupiah.
\end{abstract}

Kata Kunci: PDRB; Perusahaan Industri; Jumlah Tenaga Kerja; Pertambangan; Area Perkebunan; Analisis Regresi Linear Berganda

\section{Diterbitkan Oleh:}

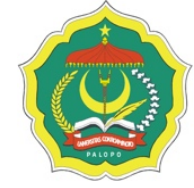

\author{
Fakultas Sains \\ Program Studi Matematika \\ Universitas Cokroaminoto Palopo
}

Copyright (C) 2021 The Author (s)

This article is licensed under CC BY 4.0 License

\section{(cc) $\mathrm{BY}$}




\section{PENGARUH BANYAKNYA PERUSAHAAN INDUSTRI, JUMLAH TENAGA KERJA, JUMLAH PRODUKSI GALIAN/PERTAMBANGAN SERTA LUAS AREA PERKEBUNAN DAN PERIKANAN TERHADAP PDRB PROVINSI SULAWESI SELATAN}

\section{Pendahuluan}

Pertumbuhan ekonomi merupakan masalah yang terjadi dalam suatu perekonomian negara dalam jangka panjang sehingga menuju keadaan yang lebih baik pada periode tertentu serta dapat dikatakan kenaikan pendapatan nasional yaitu keadaan kenaikan kapasitas produksi suatu perekonomian. Keberhasilan pembangunan ekonomi dapatdiukur dengan melihat pertumbuhan ekonomi dalam kehidupan masyarakat (Ernita,Amar dan Syofyan, 2013).

Dalam melakukan analisis mengenai hasil pembangunan ekonomi yang telah dilaksanakan oleh suatu negara atau daerah dapat dinilai dari pertumbuhan ekonomi pada suatu negara atau daerah. Pertembuhan ekonomi dapat dikatakan mengalami pertumbuhan apabila produksi barang maupun jasa mengalami peningkatan dari tahun sebelumnya. Dampak yang dapat dilihat dari terjadinya pertumbuhan ekonomi yaitu pertumbuhan produksi barang dan jasa di suatu wilayah perekonomian dalam waktu tertentu. Semakin tinggi tingkat pertumbuhan ekonomi maka semakin cepat proses pertambahan output wilayah sehingga prospek perkembangan wilayah semakin baik. Dengan diketahuinya sumber-sumber pertumbuhan ekonomi maka dapat di tentukan sektor prioritas pembangunan (Romi dan Umiyati, 2018). Produk Domestik Regional Bruto (PDRB) merupakan salah satu alat untuk melihat pertumbuhan ekonomi dalam suatu daerah.

Menurut Sukirno (1994), beberapa faktor yang mempengaruhi pertumbuhan ekonomi yaitu:

1. Sumber daya alam

2. Jumlah tenaga kerja dan sumber daya manusia

3. Ilmu pengetahuan dan teknologi serta jumlah barang modal

4. Perilaku sosial masyarakat

Produk Domesti Regional Bruto atau disingkat PDRB merupakan total nilai barang dan jasa yang diproduksi selama kurun waktu tertentu (selama satu tahun) pada suatu wilayah atau regional tertentu. Nilai dari PDRB dapa digunakan untuk mengukur tingginya tingkat pertumbuhan ekonomi suatu negara atau daerah tersebut mengalami kemajuan pereonomian atau tidak. (Dama, Lapian, dan Sumual, 2016). 
Menurut Badan Pusat Statistik (2006) Produk Domestik Regional Bruto (PDRB) didefinisikan sebagai jumlah nilai tambah yang dihasilkan oleh seluruh unit usaha dalam suatu wilayah, atau merupakan jumlah seluruh nilai barang dan jasa akhir yang dihasilkan oleh seluruh unit ekonomi di suatu wilayah. Produk domestik suatu wilayah merupakan nilai seluruh barang dan jasa yang diproduksi diwilayah tersebut dalam satu periode tertentu.

PDRB terbagi menjadi dua kategori yaitu PDRB Atas Dasar Harga Berlaku dan PDRB Atas Dasar Harga Konstan. PDRB Atas Dasar Harga Berlaku yang menggambarkan nilai tambah barang dan jasa yang dihitung menggunakan harga pada setiap tahun, sedang PDRB Atas Dasar Harga Konstan menunjukan nilai tambah barang dan jasa yang dihitung menggunakan harga pada tahun tertentu sebagai dasar dimana dalam perhitungan ini digunakan tahun 2000 (Susanti, 2013). Laju pertumbuhan Produk Domestik Regional Bruto diperoleh dari perhitungan Produk Domestik Bruto (PDB) atas dasar harga konstan, diperoleh dengan cara mengurangi nilai PDB pada tahun ke-n terhadap nilai pada tahun ke n-1 (tahun sebelumnya), dibagi dengan nilai pada tahun ke n-1 dikalikan dengan 100\% (Badan Pusat Statistik Indonesia, 2018).

Beberapa hal yang dapat mempengaruhi peningkatan dari PDRB suatu wilayah adalah sebagai berikut:

1. Perusahaan industri (Fithriyah, 2010))

2. Tenaga kerja (Putri, 2017)

3. Pertambangan (Ernita, 2019)

4. Luas Area Perkebunan (Mona, 2015).

Analisis regresi linear berganda memiliki variabel bebas lebih dari satu. Regresi linear berganda digunakan untuk mengetahui ada tidaknya pengaruh signifikan dua atau lebih variabel bebas $\left(X_{1}, X_{2}, X_{3}, \cdots, \cdots, \cdots, k\right)$ terhadap variabel terikat $(Y)$ (Mona, John dan Jantje, 2015). Model regresi linear berganda secara umum dapat ditulis (Utami, Abdul dan Alan 2016):

$$
Y=\beta_{0}+\beta_{1} X_{1}+\beta_{2} X_{2}+\ldots+\beta_{k} X_{k}+\varepsilon
$$

Dimana:

$\mathrm{Y}=$ Variabel terikat atau dependen

$\mathrm{X}=$ Variabel bebas atau independen

$\beta=$ Slope atau koefisien estimate

$\varepsilon=$ error

$\mathrm{k}=$ Jumlah variabel

Penelitian mengenai metode regresi linier berganda pernah dilakukan oleh Padillah dan 
Riza (2019) yang meneliti tentang Analisi Regresi Linear berganda dalam estimasi produktivitas tanaman padi di Kabupaten Karawang. Tujuan dari penelitian untuk mengestimasi produktivitas tanaman padi di Kabupaten Karwang terhadap variabel yang berpengaruh. Hasil penelitian diperoleh model regresi linear berganda yaitu sebesar 80,49\% faktor-faktor produktivitas padi dapat dijelaskan oleh produksi, luas panen, luas tanam, curah hujan, dan hari hujan, sedangkan sisanya 19,54\% oleh faktor-faktor lain yang tidak diteliti dalam penelitian ini.

Pokok permasalahan dalam penelitian ini adalah untuk mengetahui pengaruhi banyaknya perusahaan industri, jumlah tenaga kerja, jumlah pertambangan dan luas area perikanan serta perkebunan terhadap produk domestik regional bruto di Provinsi Sulawesi Selatan melalui analisis regresi linear berganda.

\section{Metode Penelitian}

Data yang digunakan dalam penelitian ini adalah data sekunder yang diperolah dari Kantor Badan Pusat Statistik (BPS) Sulawesi Selatan. Penelitian ini menggunakan analisis regresi linear berganda yang didahului dengan beberapa uji asumsi klasik sebagai syarat untuk melakukan analisis regresi linear berganda. Langkah-langkah yang dilakukan dalam penelitian ini adalah:

a. Mengumpulkan data;

b. Melakukan beberapa uji asumsi klasik yang harus dipenuhi sebelum melakukan analisis regresi linear berganda yaitu:

1. Uji normalitas

2. Uji linearitas

3. Uji heteroskedastisitas

4. Uji multikolineritas

5. Uji autokorelasi

c. Menentukan model regresi linear berganda;

d. Melakukan uji hipotesis untuk mengetahui pengaruh variabel bebas terhadap variabel terikat secara simultan (bersama-sama) dan secara parsial;

e. Melakukan interpretasi dari hasil analisis yang telah diperoleh.

\section{Hasil dan Pembahasan}

Data yang digunakan dalam penelitian ini adalah data sekunder yang diperoleh dari Badan Pusat Statistika Provinsi Sulawesi Selatan selama tahun 2018 melalui situs resmi BPS berupa data Produk Domestik Bruto (Y), Jumlah Perusahaan Industri $\left(\mathrm{X}_{1}\right)$, Jumlah Tenaga Kerja $\left(\mathrm{X}_{2}\right)$, Jumlah Produksi Galian/Pertambangan $\left(\mathrm{X}_{3}\right)$ dan Luas Area Perikanan dan 
Perkebunan $\left(\mathrm{X}_{4}\right)$ (Lihat Tabel 1).

Tabel 1. PDRB, Jumlah perusahaan industri, Tenaga kerja, Pertambangan serta luas area Perikanan dan Perkebunan

\begin{tabular}{|c|c|c|c|c|c|c|}
\hline No & $\mathrm{Kab} / \mathrm{Kota}$ & $\begin{array}{l}\text { PDRB } \\
\text { (milyar) }\end{array}$ & $\begin{array}{c}\text { Jumlah } \\
\text { Perusahaan } \\
\text { Industri }\end{array}$ & $\begin{array}{l}\text { Jumlah } \\
\text { Tenaga } \\
\text { Kerja } \\
\text { (orang) }\end{array}$ & $\begin{array}{c}\text { Jumlah } \\
\text { produksi } \\
\text { Galian/ } \\
\text { Pertambangan } \\
\quad \text { (juta } \mathrm{m}^{3} \text { ) }\end{array}$ & $\begin{array}{l}\text { Luas Area } \\
\text { Perikanan } \\
\text { dan } \\
\text { Perkebunan } \\
\text { (hektar) }\end{array}$ \\
\hline 1 & Bantaeng & $7,765.07$ & 1,359 & 103,252 & 282,200 & 35,884 \\
\hline 2 & Barru & $6,612.21$ & 2,228 & 157,798 & 206,580 & 54,150 \\
\hline 3 & Bone & $33,097.90$ & 2,765 & 123,789 & 262,568 & 38,093 \\
\hline 4 & Bulukumba & $13,198.92$ & 411 & 159,431 & 178,000 & 12,563 \\
\hline 5 & Enrekang & $6,702.50$ & 386 & 101,526 & 262,878 & 48,169 \\
\hline 6 & Gowa & $19,063.90$ & 718 & 149,784 & 427,992 & 16,621 \\
\hline 7 & Jeneponto & $9,413.90$ & 1,368 & 147,172 & 268,908 & 54,920 \\
\hline 8 & Kep. Selayar & $4,666.86$ & 1,275 & 162,548 & 475,877 & 20,433 \\
\hline 9 & Luwu & $14,424.80$ & 1,873 & 144,859 & 419,515 & 47,169 \\
\hline 10 & Luwu Timur & $20,250.60$ & 1,860 & 134,795 & 768,070 & 29,978 \\
\hline 11 & Luwu Utara & $10,800.90$ & 2,820 & 141,429 & 221,497 & 67,888 \\
\hline 12 & Maros & $21,310.22$ & 319 & 139,816 & 135,007 & 14,661 \\
\hline 13 & Pangkep & $23,994.89$ & 194 & 139,173 & 235,198 & 67,070 \\
\hline 14 & Pinrang & $16,411.33$ & 3,321 & 146,653 & 430,860 & 46,820 \\
\hline 15 & Sidrap & $11,921.04$ & 3,860 & 118,164 & 618,682 & 16,018 \\
\hline 16 & Sinjai & $10,226.98$ & 251 & 115,549 & 267,972 & 27,167 \\
\hline 17 & Takalar & $9,322.84$ & 538 & 136,274 & 166,020 & 64,120 \\
\hline 18 & Tana Toraja & $6,084.80$ & 842 & 128,587 & 188,223 & 20,816 \\
\hline 19 & Toraja Utara & $7,788.40$ & 894 & 103,965 & 312,148 & 11,223 \\
\hline 20 & Wajo & $17,897.74$ & 1,405 & 117,871 & 283,641 & 34,306 \\
\hline 21 & Makassar & $16,207.28$ & 2,653 & 161,317 & 110,208 & 9,720 \\
\hline 22 & Palopo & $7,285.35$ & 926 & 167,034 & 121,593 & 9,191 \\
\hline 23 & Pare-Pare & $6,602.50$ & 1,346 & 161,911 & 216,871 & 9,119 \\
\hline
\end{tabular}

Sebelum melakukan analisis regresi linear berganda untuk menetukan model, data pada

Tabel 1 tersebut akan melalui uji asumsi klasik regresi linear berganda. Adapun uji asumsi klasik tersebut yaitu:

1. Uji Normalitas

Uji normalitas bertujuan untuk menguji apakah data yang akan digunakan berdistribusi normal atau tidak. Dalam penelitian ini uji normalitas dilihat dengan menggunakan nilai dari Shapiro-Wilk Test dengan hipotesis dan kriteria sebagai berikut:

Hipotesis pernyataan:

$$
\begin{array}{ll}
\mathrm{H}_{0} & \text { : Data mengikuti distribusi normal } \\
\mathrm{H}_{1} & \text { : Data tidak mengikuti distribusi normal }
\end{array}
$$

Kriteria pengambilan keputusan: 
- Tolak $\mathrm{H}_{0}$ apabila nilai signifkansi (Sig.) $<0.05$ berarti distribusi sampel tidak normal.

- Terima $\mathrm{H}_{0}$ apabila nilai signifikansi (Sig.) $>0.05$ berarti distribus sampel normal.

Tabel 2. Hasil Uji Normalitas Shapiro-Wilk

\begin{tabular}{llll}
\hline \multirow{2}{*}{ Variabel } & Shapiro-Wilk & \\
\cline { 2 - 4 } & Statistic & $d f$ & Sig. \\
\hline Perusahaan Industri $\left(\mathrm{X}_{1}\right)$ & 0.920 & 23 & 0.066 \\
Tenaga Kerja $\left(\mathrm{X}_{2}\right)$ & 0.940 & 23 & 0.183 \\
trans_Y & 0.947 & 23 & 0.249 \\
trans_X & 0.936 & 23 & 0.145 \\
trans_X & 0.925 & 23 & 0.084 \\
\hline
\end{tabular}

Berdasarkan Tabel 2 hasil uji normalitas setelah transformasi diperoleh nilai signifikan setiap variabel $\geq 0.05$ sehingga dari hasil tersebut diperoleh bahwa setiap variabel baik variabel dependen maupun variabel independen berdistribusi normal yang artinya tidak ada data pencilan dalam data tersebut.

2. Uji Linearitas

Uji linearitas dilakukan untuk mengetahui apakah hubungan antar variabel memiliki hubungan yang linear dalam hal ini uji kelinearitasan garis regresi dapat dilihat dengan menggunakan Tabel 4 berikut:

Tabel 3. Hasil Uji Linearitas ANOVA Test

\begin{tabular}{ccc}
\hline \multirow{2}{*}{ Kategori } & \multicolumn{2}{c}{ Deviation from Linearity } \\
\cline { 2 - 3 } & $\mathrm{F}$ & Sig. \\
\hline PDRB * LN_X & 0.983 & 0.531 \\
PDRB * LN_X & 2.617 & 0.312 \\
PDRB * LN_X & 0.503 & 0.865 \\
PDRB * LN_X & 0.884 & 0.514 \\
\hline
\end{tabular}

\section{Hipotesis:}

$H_{0}$ : Model regresi berbentuk linear

$H_{1}$ : Model regresi berbentuk non linear

Kriteria pengujian:

Menggunakan koefisien signifikasi (Sig.) dengan cara "jika nilai Sig. pada Deviation from Linearity > 0.05 maka $\mathrm{H} 0$ diterima, sebaliknya $\mathrm{H}_{0}$ ditolak".

Keputusan:

Dari Tabel 3 diatas diperoleh nilai Sig. pada Deviation from Linearity untuk variabel banyaknya perusahaan industri $\left(\mathrm{X}_{1}\right)$, tenaga kerja $\left(\mathrm{X}_{2}\right)$, produksi pertambangan $\left(\mathrm{X}_{3}\right)$ dan luas area perkebunan $\left(\mathrm{X}_{4}\right)>0.05$, sehingga $\mathrm{H} 0$ diterima untuk keempat variabel bebas tersebut. Jadi, regresi untuk ke-4 variabel berbentuk linear. 


\section{Uji Heteroskedastisitas}

Pengujian heterokedastisitas bertujuan untuk megetahui apakah terjadi variansi residual yang tidak konstan (berubah-ubah) secara sistematik sejalan dengan berubahnya variabel bebas. Dalam penelitian ini untuk uji heterokedastisitas dapat dilihat pada test Spearman's rho pada tabel correlations atau tabel korelasi.

Tabel 4. Hasil Uji Heteroskedastisitas Spearman's rho Test

\begin{tabular}{lrrrrr}
\hline \multicolumn{1}{c}{ Spearman's rho } & \multicolumn{1}{c}{ ABR } & \multicolumn{1}{c}{$\begin{array}{c}\text { Perusahaan } \\
\text { ESID }\end{array}$} & \multicolumn{1}{c}{$\begin{array}{c}\text { Tenaga } \\
\text { Kerja }\end{array}$} & $\begin{array}{c}\text { Produksi } \\
\text { Pertambangan }\end{array}$ & $\begin{array}{c}\text { Luas Area } \\
\text { Perkebunan }\end{array}$ \\
\hline ABRESID & 0 & 0.381 & 0.596 & 0.964 & 0.764 \\
Perusahaan Industri & 0.381 & 0 & 0.565 & 0.147 & 0.625 \\
Tenaga Kerja & 0.596 & 0.565 & 0 & 0.164 & 0.183 \\
$\begin{array}{l}\text { Produksi } \\
\text { Pertambangan }\end{array}$ & 0.964 & 0.147 & 0.164 & 0 & 0.538 \\
$\begin{array}{l}\text { Luas Area } \\
\text { Perkebunan }\end{array}$ & 0.764 & 0.625 & 0.183 & 0.538 & 0 \\
\hline
\end{tabular}

Hipotesis:

$\mathrm{H}_{0} \quad$ : Tidak ada hubungan yang sistematik antara variabel yang menjelaskan dan nilai mutlak dari Residualnya.

$\mathrm{H}_{1} \quad$ : Ada hubungan yang sistematik antara variabel yang menjelaskan dan nilai mutlak dari Residualnya.

Kriteria Pengujian:

Apabila koefisien signifikansi (Sig.) antara variabel bebas dengan residual mutlaknya $\left(\right.$ ABRESID) $>\alpha$, maka terima $\mathrm{H}_{0}$, sebaliknya tolak $\mathrm{H}_{0}$.

Keputusan:

Nilai koefisien signifikansi (Sig.) antara perusahaan industri $\left(\mathrm{X}_{1}\right)$, tenaga kerja $\left(\mathrm{X}_{2}\right)$, Produksi pertambangan $\left(\mathrm{X}_{3}\right)$ dan Luas area perkebunan $\left(\mathrm{X}_{4}\right)$ dengan ABRESID $>0.05$ maka terima $\mathrm{H}_{0}$ yang berarti bahwa tidak ada hubungan yang sistematik antara $\mathrm{X}_{1}, \mathrm{X}_{2}, \mathrm{X}_{3}$, dan $\mathrm{X}_{4}$ dengan nilai mutlak residualnya.

4. Uji Multikolinearitas

Pengujian ini bertujuan untuk melihat apakah dalam model regresi ditemukan korelasi yang sangat kuat antara variabel terikat (variabel independen). Model regresi sebaiknya tidak terjadi korelasi yang sangat tinggi diantara variabel bebsas (variabel independen). Dalam penelitian ini untuk mendeteksi multikolinieritas dapat dilihat dari dengan menghitung nilai Variance Inflation Factors (VIF) pada tabel Coefficients. 
Tabel 5. Hasil uji heteroskedastisitas Spearman's rho Test

\begin{tabular}{lcc}
\hline \multirow{2}{*}{\multicolumn{1}{c}{ Variabel }} & \multicolumn{2}{c}{ Collinearity Statistics } \\
\cline { 2 - 3 } & Tolerance & VIF \\
\hline Perusahaan Industri & 0.811 & 1.233 \\
Tenaga Kerja & 0.915 & 1.093 \\
Produksi Pertambangan & 0.796 & 1.256 \\
Luas Area Perkebunan & 0.956 & 1.046 \\
\hline
\end{tabular}

Hipotesis:

$\mathrm{H}_{0} \quad$ : Tidak terjadi multikolinearitas di dalam model regresi.

$\mathrm{H}_{1} \quad$ : Terjadi multikolinearitas di dalam model regresi.

Kriteria Pengujian:

Jika nilai VIF $<10.00$ maka terima H0, sebaliknya jika VIF $>10.00$ tolak H0.

Keputusan:

Nilai Collinearity Statistics VIF perusahaan industri $\left(\mathrm{X}_{1}\right)$, tenaga kerja $\left(\mathrm{X}_{2}\right)$, produksi pertambangan $\left(\mathrm{X}_{3}\right)$ dan luas area perkebunan $\left(\mathrm{X}_{4}\right)<10.00$ sehingga $\mathrm{H} 0$ diterima yang artinya bahwa tidak terjadi multikolinearitas di dalam model regresi pada variabel $X_{1}, X_{2}, X_{3}$ dan $X_{4}$.

5. Uji Autokorelasi

Pengujian ini bertujuan untuk mengetahui korelasi pada setiap data untuk semua variabel secara bersamaan dalam satu periode. Dalam penelitian ini untuk mendeteksi autokorelasi adalah dengan melakukan Durbin Watson Test dengan melihat pada tabel Model Summary.

Tabel 6. Hasil Uji Autokorelasi Durbin Watson Test

\begin{tabular}{clllll}
\hline Model & $R$ & $R$ Square & $\begin{array}{l}\text { Adjusted } R \\
\text { Square }\end{array}$ & $\begin{array}{l}\text { Std. Error of the } \\
\text { Estimate }\end{array}$ & $\begin{array}{l}\text { Durbin- } \\
\text { Watson }\end{array}$ \\
\hline 1 & $0.211^{\mathrm{a}}$ & 0.045 & -0.168 & 7630.39169 & 1.917 \\
\hline
\end{tabular}

Berdasarkan tabel 6 nilai Durbin-Watson adalah sebesar $d=1.917$ selanjutnya nilai tersebut akan dibandingkan dengan nilai tabel Durbin-Watson pada taraf eror 5\% dengan perbandingan $(\mathrm{k} ; \mathrm{n})$ untuk $\mathrm{k}$ adalah jumlah variabel bebas (variabel independen) dan $\mathrm{n}$ adalah jumlah sampel. Diketahui nilai $\mathrm{k}=4$ dan $\mathrm{n}=23$.

Rumusan Hipotesisnya adalah:

$\mathrm{H}_{0} \quad$ : Tidak adanya autokorelasi pada data

$\mathrm{H}_{1} \quad$ : Adanya autokorelasi pada data

Kriteria Pengujian:

Apabila Durbin-Watson $(d)>$ batas atas pada tabel durbin-watson $\left(d_{U}\right)$ atau DurbinWatson $(d)<4$ dikurangi batas bawah pada tabel durbin-watson $\left(d_{L}\right)$ maka terima $\mathrm{H}_{0}$, Jika tidak maka tolak $\mathrm{H}_{0}$. Jika, $d>d_{U}$ dan $d<4-d_{L}$ maka terima $\mathrm{H} 0, d<d_{L}$ atau $d>d_{L}$ maka 
tolak H0 atau $d_{U}<d<4-d_{L}$ maka tolak $\mathrm{H} 0$.

Keputusan:

Berdasarkan nilai dari tabel durbin-watson eror 5\% diperoleh $d_{U}=0.9864$ dan $d_{L}=$ 1.7855 , jika $4-d_{L}=4-1.7855=2.214$. Jika dilihat pada tabel nilai Durbin-Watson $\mathrm{d}=$ 1.917 maka $1.917>0.9864$ dan $1.917<2.214$ dari hasil tersebut maka terima H0 yang berarti tidak terdapat autokorelasi pada data.

Setelah pengujian asumsi klasik tersebut terpenuhi maka selanjutnya melakukan penentuan model dari analis regresi linear berganda.

Kegiatan analisis dimulai dengan menentukan variabel apa saja yang akan dimasukkan dan dikeluarkan dari persamaan regresi yang akan dibentuk. Hal ini dapat dilihat pada tabel 8 berikut.

Tabel 7. Deskripsi Variabel yang Masuk dan yang Keluar

\begin{tabular}{clcc}
\hline Model & \multicolumn{1}{c}{ Variables Entered } & Variables Removed & Method \\
\hline 1 & $\begin{array}{l}\text { Luas Area Perkebunan, Produksi } \\
\text { Pertambangan, Tenaga Kerja, } \\
\text { Perusahaan Industrib }\end{array}$ & 0 & Enter \\
\hline
\end{tabular}

Tabel 7 menunjukkan variabel apa saja yang akan diproses atau diolah kedalam model regresi atau dengan kata lain, perusahaan industri $\left(\mathrm{X}_{1}\right)$, tenaga kerja $\left(\mathrm{X}_{2}\right)$, produksi pertambangan $\left(\mathrm{X}_{3}\right)$, dan luas area perkebunan $\left(\mathrm{X}_{4}\right)$ dimasukkan kedalam pengolahan model regresi regresi.

Tabel 8. Deskripsi Hubungan Antar Variabel

\begin{tabular}{cccc}
\hline Model & R & R Square & Adjusted R Square \\
\hline 1 & 0.423 & 0.179 & 0.004 \\
\hline
\end{tabular}

Berdasarkan tabel 8 terlihat bahwa koefisien korelasi multiple diperoleh $\mathrm{R}=0.423$ berarti hubungan variabel $\mathrm{X}_{1}, \mathrm{X}_{2}, \mathrm{X}_{3}$, dan $\mathrm{X}_{4}$ dengan $\mathrm{Y}$ pada penelitian ini dalam kategori lemah. Tingkat hubungan diantara variabel $\mathrm{X}_{1}, \mathrm{X}_{2}, \mathrm{X}_{3}$, dan $\mathrm{X}_{4}$ dengan $\mathrm{Y}$ dilihat dari $R$ Square $\left(\mathrm{R}^{2}\right)=$ 0.179 atau $17.9 \%$ yang artinya pengaruh variabel bebas terhadap variabel terikat (PDRB (Y)) adalah sebesar $17,9 \%$ sedangkan $82,1 \%$ dipengaruhi oleh faktor lain selain dari variabel $\mathrm{X}_{1}, \mathrm{X}_{2}$, $\mathrm{X}_{3}$, dan $\mathrm{X}_{4}$.

Tabel 9. Deskripsi Pengaruh Variabel Bebas dengan Variabel Terikat

Hipotesis:

\begin{tabular}{ccc}
\hline Model & F & Sig. \\
\hline Regression & 1.980 & 0.044 \\
\hline
\end{tabular}

$\mathrm{H}_{0} \quad$ : Perusahaan industri $\left(\mathrm{X}_{1}\right)$, tenaga kerja $\left(\mathrm{X}_{2}\right)$, produksi pertambangan $\left(\mathrm{X}_{3}\right)$, dan luas area perkebunan $\left(\mathrm{X}_{4}\right)$ tidak berpengaruh Terhadap PDRB (Y) 
$\mathrm{H}_{1} \quad$ : Perusahaan industri $\left(\mathrm{X}_{1}\right)$, tenaga kerja $\left(\mathrm{X}_{2}\right)$, produksi pertambangan $\left(\mathrm{X}_{3}\right)$, dan luas area perkebunan $\left(\mathrm{X}_{4}\right)$ berpengaruh Terhadap PDRB (Y)

Kriteria pengambilan keputusan:

Apabila Signifikansi (Sig.) $<0.05$ maka H0 ditolak atau signifikan. Sebaliknya H0 diterima.

Keputusan:

Berdasarkan tabel 9 nilai Sig. $=0.044<0.05$ maka H0 ditolak yang artinya Perusahaan Industri $\left(X_{1}\right)$, Tenaga Kerja $\left(X_{2}\right)$, Produksi Pertambangan $\left(X_{3}\right)$, dan Luas Area Perkebunan $\left(X_{4}\right)$ berpengaruh Terhadap PDRB (Y) di Sulawesi Selatan.

Tabel 10. Model Regresi Linear Berganda

\begin{tabular}{lrr}
\hline \multirow{2}{*}{ Variabel Bebas } & \multicolumn{2}{c}{ Unstandardized Coefficients } \\
\cline { 2 - 3 } & \multicolumn{1}{c}{ B } & Sig. \\
\hline (Constant) & 135.789 & 0.010 \\
Perusahaan Industri & 5.502 & 0.035 \\
Tenaga Kerja & -23.592 & 0.181 \\
Produksi Pertambangan & 0.180 & 0.039 \\
Luas Area Perkebunan & 1.411 & 0.029 \\
\hline
\end{tabular}

Berdasarkan Tabel 10 diperoleh nilai pada kolom B yang menyatakan keefisien dari setiap variabel bebas, sedangkan untuk kolom Sig. menyatakan bahwa apakah setiap variabel dapat dimasukkan ke dalam model regresi linear berganda. Pengujian hipotesi dilakukan untuk melihat variabel apasaja yang akan dimasukkan ke dalam model regresi linear berganda yaitu dengan melihat nilai sig. pada Unstandardized Coefficients.

Hipotesis:

$\mathrm{H}_{0} \quad$ : tidak ada pengaruh yang nyata variabel bebas (perusahaan industri $\left(\mathrm{X}_{1}\right)$, tenaga kerja $\left(\mathrm{X}_{2}\right)$, produksi pertambangan $\left(\mathrm{X}_{3}\right)$, dan luas area perkebunan $\left.\left(\mathrm{X}_{4}\right)\right)$ terhadap variabel terikat (PDRB (Y))

$\mathrm{H}_{1}$ : ada pengaruh yang nyata variabel bebas (perusahaan industri $\left(\mathrm{X}_{1}\right)$, tenaga kerja $\left(\mathrm{X}_{2}\right)$, produksi pertambangan $\left(\mathrm{X}_{3}\right)$, dan luas area perkebunan $\left(\mathrm{X}_{4}\right)$ ) terhadap variabel terikat $(\operatorname{PDRB}(\mathrm{Y}))$

Kriteria pengambilan keputusan:

Apabila Signifikansi (Sig.) $<0.05$ maka H0 ditolak atau signifikan. Sebaliknya H0 diterima. Keputusan:

Berdasarkan Tabel 10 diperoleh nilai signifikan untuk setiap variabel yaitu:

a. Nilai sig. untuk variabel perusahaan industri $\left(\mathrm{X}_{1}\right)$, produksi pertambangan $\left(\mathrm{X}_{3}\right)$ dan Luas area perkebunan $\left(\mathrm{X}_{4}\right)$ adalah $<0.05$ maka $\mathrm{H} 0$ ditolak yang artinya variabel perusahaan 
industri $\left(\mathrm{X}_{1}\right)$, produksi pertambangan, dan luas area perkebunan berpengaruh nyata terhadap variabel PDRB (Y) sehingga dimasukkan ke dalam model regresi linear berganda.

b. Nilai sig. untuk variabel tenaga kerja $\left(\mathrm{X}_{2}\right)$ adalah $>0.05$ maka H0 diterima yang artinya variabel tenaga kerja $\left(\mathrm{X}_{2}\right)$ tidak berpengaruh nyata terhadap variabel PDRB (Y) sehingga variabel tenaga kerja $\left(\mathrm{X}_{2}\right)$ tidak dimasukkan ke dalam model regresi linear berganda.

Setelah menentukan variabel yang akan dimasukkan kedalam model maka selanjutnya pembentukan model regresi linear berganda sesuai dengan persamaan (1). Berdasarkan tabel 10 terlihat bahwa konstanta $\beta_{0}=135.789$, koefisien $\beta_{1}=5.502$, dan $\beta_{3}=0.180$, dan $\beta_{4}=$ 1.411 sehingga model persamaan regresinya sebagai berikut:

$$
Y=135.789+5.502 X_{1}+0.180 X_{3}+1.411 X_{4}+\varepsilon
$$

Dari model tersebut diperoleh:

1. Konstanta sebesar 135.789 menyatakan bahwa jika perusahaan industri $\left(\mathrm{X}_{1}\right)$, produksi pertambangan $\left(\mathrm{X}_{3}\right)$, dan luas area perkebunan $\left(\mathrm{X}_{4}\right)$ bernilai $=0$ maka nilai PDRB Provinsi Sulawesi Selatan sebesar 135.789 milyar rupiah.

2. Koefisien regresi untuk $X_{1}$ sebesar 5,502 bernilai positif artinya penambahan satu unit perusahaan industri $\left(\mathrm{X}_{1}\right)$ di Provinsi Sulawesi Selatan maka akan meningkatkan nilai PDRB di Provinsi Sulawesi Selatan sebesar 5,502 milyar rupiah, begitupun sebaliknya.

3. Koefisien regresi untuk $X_{3}$ sebesar 0,180 bernilai positif artinya penambahan jumlah produksi pertambangan $\left(\mathrm{X}_{3}\right)$ sebesar 1 juta $\mathrm{m}^{3}$ di Provinsi Sulawesi Selatan maka akan meningkatkan nilai PDRB di Provinsi Sulawesi Selatan sebesar 0,180 milyar rupiah, begitupun sebaliknya.

4. Koefisien regresi untuk $\mathrm{X}_{4}$ sebesar 1,411 bernilai positif artinya penambahan 1 hektar luas area perkebunan $\left(\mathrm{X}_{4}\right)$ di Provinsi Sulawesi Selatan maka akan meningkatkan nilai PDRB di Provinsi Sulawesi Selatan sebesar 1,411 milyar rupiah, begitupun sebaliknya.

Jadi, dapat disimpulkan bahwa banyaknya perusahaan industri, jumlah produksi pertambangan, dan luas dari area perkebunan yang berada di setiap kabupaten/kota di Provinsi Sulawesi Selatan mempengaruhi nilai Produk Domestik Regional Bruto di Provinsi Sulawesi Selatan.

\section{Kesimpulan}

Dari hasil analisi yang diperoleh dari data Produk Domestik Regional Bruto yang dari 23 kabupaten/kota di Provinsi Sulawesi Selatan yang telah dijelaskan dalam pembahasan sebelumnya dapat ditarik kesimpulan bahwa model regresi linear berganda untuk menganilis pertumbuhan ekonomi di Provinsi Sulawesi Selatan yaitu $Y=135.789+5.502 X_{1}+$ 
$0.180 X_{3}+1.411 X_{4}+\varepsilon$. Dari hasil analisis diperoleh adanya pengaruh positif variabel jumlah perusahan industry $\left(\mathrm{X}_{1}\right)$, banyaknya produksi pertambangan $\left(\mathrm{X}_{3}\right)$, dan luas dari area perkebunan $\left(\mathrm{X}_{4}\right)$ terhadap nilai PDRB di Provinsi Sulawesi Selatan. Jika penambahan satu unit perusahaan industri di Provinsi Sulawesi Selatan maka akan meningkatkan nilai PDRB di Sulawesi selatan sebesar 5,502 milyar rupiah. Jika penambahan jumlah produksi pertambangan sebesar 1 juta $\mathrm{m}^{3}$ di Provinsi Sulawesi Selatan maka akan meningkatkan nilai PDRB di Sulawesi selatan sebesar 0,180 milyar rupiah. Sedangkan jika terjadi penambahan 1 hektar luas area perkebunan (X4) di Provinsi Sulawesi Selatan maka akan meningkatkan nilai PDRB di Sulawesi selatan sebesar 1,411 milyar rupiah.

\section{DAFTAR PUSTAKA}

Badan Pusat Statistik. 2018.Provinsi Sulawesi Selatan dalam Angka 2018. BPS: Sul-Sel.

Dama, Yudistira., Himawan, Agnes L Ch Lapian, Jacline I. Sumual. 2016. Pengaruh Produk Domestik Regional Bruto (PDRB) Terhadap Tingkat Kemiskinan di Kota Manado (Tahun 2005-2014). Jurnal Berkala Ilmiah Efisiensi. Vol. 16, No. 03.

Fithriyah, Zulfita. 2010. Pengaruh Kredit Bank Perbankan Terhadap Pertumbuhan Industri Munafaktur dalam Menunjang Pertumbuhan Ekonomi di Indonesia. Jurnal Ekonomi Pembangunan, Vol 8. No 1.

Mona, Margaretha G., John S. Kekenusa dan Jantje D Prang. 2015. Penggunaan Regresi Linear Berganda untuk Menganalisis Pendapatan Petani Kelapa. Skripsi. FMIPA, UNSRAT Manado.

Prishardoyo, Bambang. 2008. Analisis Tingkat Pertumbuhan Ekonomi dan Potensi Ekonomi Terhadap Produk Domestik Regional Bruto (PDRB) Kabupaten Pati Tahun 20002005.JEJAK: Jurnal Ekonomi dan Kebijakan. Vol.1, No. 1.

Putri, Novia Dita, Sudarti, dan Syamsul Hadi. 2017. Analisis Pengaruh Pertumbuhan Ekonomi dan Jumlah Angkatan Kerja Terhadap Jumlah Pengangguran di Kota Batu.Jurnal Ekonomi. Vol.1, Jilid.3.

Romi, Syahrur, dan Etik Umiyati. 2018. Pengaruh Pertumbuhan Ekonomi dan Upah Minimum Terhadap Kemiskinan di Kota Jambi.E-Jurnal Perspektif Ekonomi dan Pembangunan Daerah. Vol.7, No.1.

Sukirno, S. 1994. Pengantar Teori Ekonomi Makro. Jakarta: Raja Grafindo.

Susanti Sussy. 2013. Pengaruh Produk Domestik Regional Bruto, Pengangguran dan Indeks Pembangunan Manusia terhadap Kemiskinan di Jawa Barat dengan Menggunakan Analisis Data Panel. Jurnal Matematika Integratif. Vol. 9, No.1. 